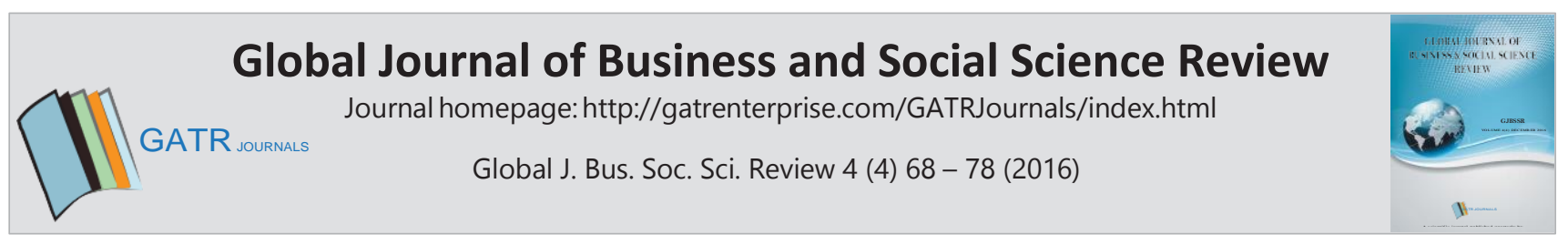

\title{
Implementation of Accounting Standard on Small and Medium-Sized Entities (SMEs)
}

\author{
Hendrian $^{1}$ and Rini Dwiyani Hadiwidjaja ${ }^{2}$ \\ 1,2 Universitas Terbuka, Jalan Cabe Raya, 15418, South of Tangerang, Indonesia
}

\begin{abstract}
Objective - Small- and medium-sized entities (SMEs) have an important role in economic growth. SMEs are a key source of employment and economic growth in Indonesia. Unfortunately, the growth of SMEs is not accompanied by the implementation of accounting and reporting, in accordance with applicable of Indonesian Accounting Standards for NonPublicly-Accountable Entities (SAK-ETAP). SAK-ETAP is a self-contained of accounting standard for many transactions and events that a small or medium-sized entity or a private entity that is not publicly accountable may face. This research aims to analyse the implementation of Indonesian Accounting Standard for Non-Publicly-Accountable Entities on SMEs.

Methodology/Technique - This research was conducted with the approach of surveys and field observations. The collection of data through surveys using questionnaires, direct observation and interviews according to respondents' experiences. Unit of analysis in this study is organizational or business unit. Its mean, that this study uses the organization as the subject to conclude the process of identification, implementation and evaluation Indonesian Accounting Standards for Non-PubliclyAccountable Entities or SMEs.

Findings - The results of this study showed that only a small percentage of SMEs that have used SAK-ETAP as a guide in the preparation of the accounting and financial statements. This contrasts with the important role of SMEs in GDP of almost $58 \%$. For that is very necessary the role of related institutions in supporting the development of SMEs in Indonesia, particularly in the financial statements standard. The majority of SMEs just recording to identify the transaction and recording the amount of revenue. Primary problem faced was the lack of their knowledge of SAK-ETAP and the competence of accounting staff were less.

Novelty - This financial report is a major concern, as the financial statements providing financial information, financial performance, and cash flows of business units. If there are weaknesses in recording in the financial statements of SMEs it becomes a challenge for an institution that is competent to fix it. Socialization and guidance of SAK-ETAP are needed and more intensive to SMEs in Indonesia.
\end{abstract}

Type of Paper: Empirical

Keywords: Accounting Standard, small- and medium-entities (SMEs), SAK-ETAP, Indonesia.

JEL Classification: L26, L29, M41.

\footnotetext{
* Paper Info: Revised: September 17, 2016

Accepted: October 11, 2016

* Corresponding author:

E-mail: dwiyani.rini@gmail.com

Affiliation: Universitas Terbuka, Indonesia
} 


\section{Introduction}

The ability of small- and medium-entities (SMEs) in Indonesia's economy is supported by various stakeholders, including government, banking and financial institutions and the community. That is, the spirit and the development of SMEs have become the focus of the government for the economic crisis in Indonesia. The government has tried to encourage SMEs to continue to provide financial assistance through the Business Credit.

Most of the people had paid less attention to the role and capability of SMEs for a business, for this appears to have contributed to the economic development. This can be seen during the economic crisis in Indonesia. SMEs were able to adjust and survive at a time when many large companies went into bankruptcy and made layoffs in large numbers. SMEs in the national economy has an important and strategic role, it is supported by the data as presented in Table 1 below.

Table 1. Development of SMEs in the period 2009 -2013

\begin{tabular}{|c|c|c|c|c|c|c|c|}
\hline No. & Indicators & Unit & 2009 & 2010 & 2011 & 2012 & 2013 \\
\hline 1 & Number of SMEs & unit & 52764603 & 53823732 & 55206444 & 56534592 & 57895721 \\
\hline 2 & Growth of SMEs & Percent & 2.64 & 2.01 & 2.57 & 2.41 & 2.35 \\
\hline 3 & $\begin{array}{l}\text { Total Workforce } \\
\text { SMEs }\end{array}$ & Person & 96211332 & 99401775 & $\begin{array}{l}101722 \\
458\end{array}$ & $\begin{array}{l}107657 \\
509\end{array}$ & $\begin{array}{l}114144 \\
082\end{array}$ \\
\hline 4 & $\begin{array}{l}\text { Growth of } \\
\text { Workforce SMEs }\end{array}$ & Percent & 2.33 & 3.32 & 2.33 & 5.83 & 5.68 \\
\hline 5 & $\begin{array}{l}\text { GDP contribution of } \\
\text { SMEs (constant } \\
\text { prices) }\end{array}$ & $\begin{array}{l}\text { Rp. } \\
\text { billion }\end{array}$ & $\begin{array}{l}1212 \\
599.30\end{array}$ & $\begin{array}{l}1282 \\
571.80\end{array}$ & $\begin{array}{r}1369 \\
326.00\end{array}$ & $\begin{array}{r}1504 \\
928.20\end{array}$ & $\begin{array}{r}1536 \\
918.80\end{array}$ \\
\hline 6 & $\begin{array}{l}\text { Growth in GDP } \\
\text { contribution of } \\
\text { SMEs }\end{array}$ & Percent & 4.02 & 5.77 & 6.76 & 9.90 & 2.08 \\
\hline
\end{tabular}

Source: https://www.bps.go.id/linkTabelStatis/view/id/1322

Table 1 shows that the number of SMEs over the last 5 years, i.e. between 2009 to 2013, increased by $8.86 \%$ with an increase in employment of 17.93 million or $15.71 \%$ of the total workforce and the increasing contribution of SMEs significant in the formation of Gross Domestic Product (GDP) at constant prices.

Although progress of SMEs very rapidly, businessmen in SMEs still have a weak understanding of the accounting and financial statements and the urgency of its use. They still tend to make decisions based on intuition and experience. Therefore, it is necessary to equip them with the knowledge of accounting and reporting. Based on the findings in the field, they conduct financial records of SMEs are generally very simple and tend to ignore the standard financial rules, including the application of accounting standards for Non-Publicly-Accountable Entities.

One of the supporters of good quality SMEs is how to prepare and implement a financial statement. The financial statements are very important to provide information on financial position of an enterprise that will benefit a large number of users in making economic decisions as well as showing the work done so management or management responsibility over resources (SFAS No. 2004).

The financial statements are accurate and standard will help the SMEs in business development, management accountability needed for the credit requirements of banks and other financial institutions. For example, in banking credit, SMEs need to have financial statements prepared in accordance with the basic standards and generally acceptable. Banks will be easier to respond and assess the feasibility of SMEs to obtain business credit. Fortunately, the Financial Accounting Standards Board Accounting Association of Indonesia has set up the Financial Accounting Standards aimed at micro, small and medium enterprises so-called Entities without Public Accountability (SAK- ETAP). 
SAK ETAP will assist SMEs in providing financial reporting remains relevant and reliable, and not get caught in the complexities of IFRS-based standards to be adopted in the Accounting Standard IAS. SAK ETAP has effectively been in place since January 2011.

The application of SFAS-ETAP can be considered as a breakthrough and a step forward in the development of the application of accounting to the level of micro, small, and medium-sized enterprises. SAK-ETAP is a principle, procedure, method, or rule of preparation of financial statements in Entity without Public Accounting (ETAP). An entity without Public Accounting (ETAP) is a business entity that is not (yet) listed on the stock market or not in the process of filing in the capital markets and the entity is not a financial institution. One of the business entities which is referred to in the standard economic small and medium enterprises (SMEs).

Vasek (2010) describes the development of the IFRS for SMEs as an alternative to the full implementation of IFRS. International Accounting Standards Board (IASB) starting to realize the complexity of the implementation of IFRS for the full service company. In June 2004, the project exposure draft IFRS for SMEs was developed. The main objective of this project is to create the conditions and requirements to meet the different needs of users of SME information. In addition, other objectives to aim at a balance between the costs and benefits associated with the adoption of IFRS. Support for this project has shown with the expanding adoption of IFRS continuously in the world. The more countries that require or permit to use IFRS as companies prepare financial statements separate or consolidated. This fact not only the public company, but also to the SMEs.

In Indonesia, Accounting Standards for SMEs known as SAK-ETAP adopted Financial Accounting Standards by IFRS are still overly complicated to be implemented by SMEs in Indonesia. These complexities will led to the cost of compliance bigger as stated by Eierle and Haller (2010). The purpose of SAK-ETAP are not only as eligible financial accounting standards for SMEs or companies that have not gone public, but also as an initial training in preparation of financial statements towards the company going public. At first the idea that triggers are SAK-ETAP is to follow the "IFRS for SMEs". However, after in-depth research, IFRS for SMEs was not simple for SMEs in Indonesia. According to the Accounting Standards Board shows Indonesian Institute of Accountants (DSAK-IAI), SAK-ETAP is an accounting standard is considered more suited to the conditions in Indonesia.

SAK-ETAP is one of the three pillars of financial accounting standards in Indonesia with SFAS (Statement of Financial Accounting Standards) and PSAS (Islamic Accounting Standards). Some characteristics of SAK-ETAP is its stand-alone standard, which means it is not dependent on GAAP, only the common set of transactions carried out by micro, small and medium enterprises, the majority uses the concept of historical boarding, setting a more modest standard compared with GAAP and will not change in some year. Should some of these characteristics are properly utilized, it could bring positive result of the application of accounting at the level of SMEs.

Although SAK-ETAP has been applied since 3 years ago, it seems that the development of SAK-ETAP implementation in SMEs is still not encouraging. Not many SMEs have applied it and the majority of them are not applied in accordance with the rules and principles contained in the SAK-ETAP. In addition, the regulations might have encouraged (and triggered) it. In comparison, previous cooperative reference to IAS number 27 have been asked to abandon the use of IAS through PPSAK (Revelation Revocation of Financial Accounting Standards) No. 8, 2010. Since January 1, 2012, the Financial Accounting Standards cooperative use of new accounting policies and as a transitional measure passed Circular Letter No. Deputy Institutional KUKM $200 /$ SE / Dep.I / XII / 2012. Since December 2011 conveyed to the department in charge of the affairs of cooperatives and SMEs province, on the revocation of SFAS No. 27 and the use of SAK ETAP (Setyo, 2012). It is also, then, strengthen with Candy KUKM No.04/Per/M.KUKM/VII/2012 on General Guidelines Cooperative Indonesia. Therefore, the weak implementation can be identified as the main problem.

Based on the background described, then we propose that the problem consists of:

1. How does the implementation of accounting standards (SAK-ETAP) for SMEs in preparing the Financial Statements

2. What are the barriers faced by SMEs in the implementation of the accounting standards (SAK-ETAP)? 
This study aims to identify, assess and evaluate on the implementation of accounting standards for SMEs in preparing the financial statements and identify any obstacles faced by SMEs in the application of accounting standards. The process of preparation of financial statements of SMEs have an influence on the performance of SMEs.

This research is expected to be beneficial for all parties. From the Government, expected to be useful in assessing the financial performance of SMEs, particularly the implementation of Accounting Standards (SAK ETAP) in preparing the financial statements. For SMEs themselves to survive and develops in a business environment by understanding and implementing SAK ETAP.

\section{Literature Review}

\subsection{Definition and Characteristics of Small and Medium Enterprises}

According to Law of the Republic of Indonesia Number 20 year 2008, the small enterprises is a business entity that has the following criteria:

a. The net worth of more than USD 50,000,000.00 (fifty million dollars) up to a maximum of Rp 500,000,000.00 (five hundred million) excluding land and buildings; and

b. Has an annual sales turnover of more than Rp300,000,000.00 (three hundred million dollars) up to a maximum of $\mathrm{Rp} 2,500,000,000.00$ (two billion five hundred million rupiah).

While Medium Enterprises is a business entity that has the following criteria:

a. The net worth of more than USD 500,000,000.00 (five hundred million rupiah) up to a maximum of Rp 10,000,000,000.00 (ten billion dollars), excluding land and buildings; and

b. Has an annual sales turnover of more than Rp2.500.000.000,00 (two billion five hundred million dollars) up to a maximum of Rp.50,000,000,000.00 (fifty billion dollars).

SMEs have several major characteristics, namely: (1) Type of goods or commodities generally remained cultivated volatility, (2) Location / place of business generally have settled not to move, (3) In general, have done simple financial administration, separated company's finance with the personal/family finances, has made the balance of the business, (4) It has a business license and other legal requirements, including TIN, (5) human resources (entrepreneurs) have experience in business, (6) Have access to banks in terms of capital expenditure, and (7) Most have not been able to make such good business management with business planning. Tambunan (2009) also gave an overview of the characteristics of SMEs as shown in Table 2 below.

Tabel 2 Characteristics of Primary Micro, Small, and Medium-Entities

\begin{tabular}{|l|l|l|l|l|}
\hline No & Aspec & Micro entities & Small entities & Medium entities \\
\hline 1 & Formality & $\begin{array}{l}\text { Operating in the informal } \\
\text { sector; business is not } \\
\text { registered; No / rarely pay } \\
\text { taxes }\end{array}$ & $\begin{array}{l}\text { Some operate in the } \\
\text { formal sector; some are } \\
\text { not registered; few who } \\
\text { pay taxes }\end{array}$ & $\begin{array}{l}\text { All in the formal } \\
\text { sector; registered and } \\
\text { pay taxes }\end{array}$ \\
\hline 2 & $\begin{array}{l}\text { Organization and } \\
\text { Management }\end{array}$ & $\begin{array}{l}\text { performed by the owner; } \\
\text { does not apply internal of } \\
\text { labor division (ILD), } \\
\text { management and } \\
\text { organizational structure } \\
\text { formal (MOF), accounting } \\
\text { system (ACS) }\end{array}$ & $\begin{array}{l}\text { performed by the } \\
\text { owner; no ILD, MOF, } \\
\text { ACS }\end{array}$ & $\begin{array}{l}\text { Many that employs } \\
\text { professional managers } \\
\text { and implementing ILD, } \\
\text { MOF, ACS }\end{array}$ \\
\hline 3 & $\begin{array}{l}\text { Employment } \\
\text { Opportunities }\end{array}$ & $\begin{array}{l}\text { Most use family members } \\
\text { as unpaid }\end{array}$ & $\begin{array}{l}\text { Some users of salaried } \\
\text { workforce }\end{array}$ & $\begin{array}{l}\text { All use salaried } \\
\text { workforce; all have }\end{array}$ \\
\hline
\end{tabular}




\begin{tabular}{|c|c|c|c|c|}
\hline No & Aspec & Micro entities & Small entities & Medium entities \\
\hline & & & & $\begin{array}{l}\text { formal recruitment } \\
\text { system }\end{array}$ \\
\hline 4 & Production process & $\begin{array}{l}\text { The degree of } \\
\text { mechanization is very low } \\
\text { / general user; technology } \\
\text { level is very low }\end{array}$ & $\begin{array}{l}\text { Some use the latest } \\
\text { machines }\end{array}$ & $\begin{array}{l}\text { Many have a high } \\
\text { degree of } \\
\text { mechanization / have } \\
\text { access to high-tech }\end{array}$ \\
\hline 5 & Market Orientation & $\begin{array}{l}\text { Usually they sell to the } \\
\text { local market for low- } \\
\text { income groups }\end{array}$ & $\begin{array}{l}\text { Many are sell to } \\
\text { domestic and export } \\
\text { markets, and serves } \\
\text { middle to upper class }\end{array}$ & $\begin{array}{l}\text { All sell to domestic and } \\
\text { export markets, and } \\
\text { serves middle to upper } \\
\text { class }\end{array}$ \\
\hline 6 & $\begin{array}{l}\text { Profile of the } \\
\text { Economic and } \\
\text { Social Business } \\
\text { Owners }\end{array}$ & $\begin{array}{l}\text { Low education and poor } \\
\text { households; prime } \\
\text { motivation: survival }\end{array}$ & $\begin{array}{l}\text { Many are well } \\
\text { educated and from non- } \\
\text { poor households; } \\
\text { highly motivated many } \\
\text { businesses / for-profit }\end{array}$ & $\begin{array}{l}\text { Most of the well- } \\
\text { educated and in } \\
\text { affluent households; } \\
\text { prime motivation: } \\
\text { profit }\end{array}$ \\
\hline 7 & $\begin{array}{l}\text { Sources of Raw } \\
\text { Materials and } \\
\text { Capital }\end{array}$ & $\begin{array}{l}\text { Most use local raw } \\
\text { materials and capital of } \\
\text { their own money }\end{array}$ & $\begin{array}{l}\text { Some use imported raw } \\
\text { materials and have } \\
\text { access to formal credit }\end{array}$ & $\begin{array}{l}\text { Many who use } \\
\text { imported raw materials } \\
\text { and have access to } \\
\text { formal credit }\end{array}$ \\
\hline 8 & External Relations & $\begin{array}{l}\text { Most do not have access to } \\
\text { the government programs } \\
\text { and had no business } \\
\text { relationship with big } \\
\text { business }\end{array}$ & $\begin{array}{l}\text { Many have access to } \\
\text { the government } \\
\text { programs and having } \\
\text { business with big } \\
\text { business }\end{array}$ & $\begin{array}{l}\text { Most have access to the } \\
\text { government programs } \\
\text { and many have } \\
\text { business relations with } \\
\text { big business }\end{array}$ \\
\hline 9 & $\begin{array}{l}\text { Women } \\
\text { Entrepreneurs }\end{array}$ & $\begin{array}{l}\text { The ratio of women to } \\
\text { men as entrepreneurs is } \\
\text { very high }\end{array}$ & $\begin{array}{l}\text { The ratio of women to } \\
\text { men as entrepreneurs is } \\
\text { quite high }\end{array}$ & $\begin{array}{l}\text { The ratio of women to } \\
\text { men as an entrepreneur } \\
\text { are very low. }\end{array}$ \\
\hline
\end{tabular}

Source: Tambunan, 2009

\subsection{Financial Statements}

According to J. Fred Weston and Thomas E. Copeland (in Sawir, 2001), "Financial Statements is a report containing the results of the calculation of the accounting process that shows the financial performance of a company at a particular time". According Kieso, (2007: 2) financial statements are the primary means of communicating financial information to parties outside the company. This report displays the history of companies that are quantified in monetary value. The objective of financial statements is to provide information of financial position, financial performance, and cash flows of an entity that is useful for a large number of users in making economic decisions by anyone who is not in a position to ask for financial reports to meet specific information needs. In fulfilling its purpose, the financial statements also show what has been done management (stewardship) or the accountability of management for the resources entrusted to it (SAK ETAP 2009: 2)

\subsection{Financial Accounting Standards Entities Without Public Accountability (SAK ETAP)}

Financial Accounting Standards for Entities without Public Accountability (SAK ETAP) is intended for use entities without public accountability. Entities without public accountability is an entity that:

a. Does not have a significant public accountability; and 
b. Publish general purpose financial statements (general-purpose financial statements) to external users. Examples of external users are the owner who is not directly involved in business management, creditors, and credit rating agencies.

An entity can be declared has a significant public accountability if the entity has filed a registration statement, or in the process of filing the registration statement, on the authority or regulator of the capital market for the purpose of issuance of securities in the capital markets or entity control assets in a fiduciary capacity for a large group of the community, such as banks, an insurer, broker or securities dealer, pension funds, mutual funds and investment banks. Entities that have public accountability may use SAK ETAP if the competent authority, which makes regulations, permit the use of SAK ETAP.

\subsection{The influence of Implementation of SAK ETAP For SMEs}

Table 3 illustrates the positive influence of an implementation of SAK ETAP to SMEs being viewed from the perspective of the financial statements, management activities, and relationships with third parties and also for the university or other institution. The important thing is financial statements that have applied SAK ETAP so that it can support the planning and operating of good corporate.

Tabel 3 The influence of Implementation of SAK ETAP For SMEs

\begin{tabular}{|c|c|c|c|}
\hline Financial Statements & Management Activities & $\begin{array}{l}\text { The relationship with } \\
\text { third party (bank) }\end{array}$ & Universities \& parties \\
\hline $\begin{array}{l}\text { CAAO namely: } \\
\text { 1. Conduct } \\
\text { 2. Accurate } \\
\text { 3. Accountable } \\
\text { 4. Open/Transparent }\end{array}$ & $\begin{array}{l}\text { - decision-making } \\
\text { - business expansion an } \\
\text { increase inthe } \\
\text { efficiency, } \\
\text { effectiveness and } \\
\text { productivity of the } \\
\text { business }\end{array}$ & $\begin{array}{l}\text { - Access to credit and } \\
\text { capital } \\
\text { - Bankable } \\
\text { - a systematic approach } \\
\text { in venture funding }\end{array}$ & $\begin{array}{l}\text { - Tridarma higher } \\
\text { education } \\
\text { - implementation theory } \\
\text { (practical) } \\
\text { - Improving the quality } \\
\text { of students (academic } \\
\text { community) } \\
\text { - jobs opportunity (as a } \\
\text { consultant / trainer) }\end{array}$ \\
\hline $\begin{array}{l}\text { Strengthening one } \\
\text { accounting standard } \\
\text { consists of GAAP and } \\
\text { IFRSs ETAP Sharia. }\end{array}$ & $\begin{array}{l}\text { Increased professionalism } \\
\text { of human resources and } \\
\text { business }\end{array}$ & $\begin{array}{l}\text { Synergy between the } \\
\text { entities and investors }\end{array}$ & government \\
\hline
\end{tabular}

\subsection{Research Model}

This study was designed to identify some important things about the implementation of accounting standards (SAK-ETAP) on small and medium enterprises. The key points are the existing condition of the implementation of accounting standards on SMEs and then explain how to shape the implementation of SAK-ETAP on SMEs. The research model of this study illustrated by Figure 1 below. 


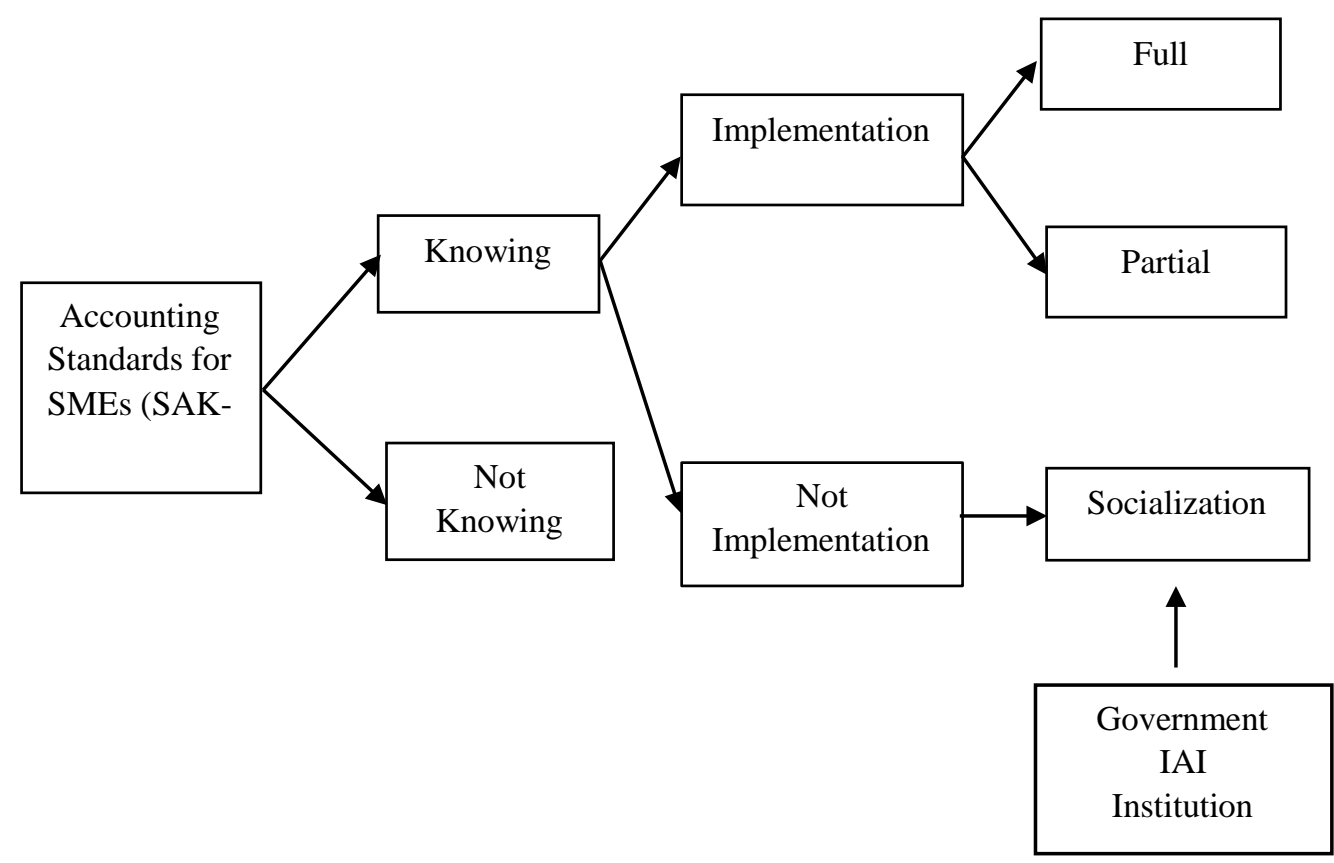

Figure 1. Research Model

\section{Methodology}

\subsection{Research Design}

This research conducted was directed so the research can be reviewed from several aspects. In terms of the purpose, the research is applied research, where the research is directed to obtain information that can be used in solving the problem. (Sugiyono, 1999: 5).

The research method with quantitative methods (naturalistic), accompanied by additional qualitative information on the field.

Unit of analysis in this study is organizational. Thus, this study uses the organization as the subject to conclude the process of identification, review and evaluation. In other words, this study is not using the unit of analysis on an individual basis, which means individual opinion as to conclude the analysis of the subject. Meanwhile, the subject domain of the study includes the following things:

- Application of accounting is the use of skills and knowledge in recording, classifying, summarizing, processing and presenting data, transactions and events related to finance so they can be used and understood easily by people for making decisions as well as other purposes.

- The financial statements of SMEs are simple bookkeeping made by SME managers to measure the performance of the business, whether your business benefit or detriment.

- The financial statements made based on GAAP and financial statements made based on the SAK ETAP, and financial statements is expected to facilitate SMEs in presenting the financial statements in accordance with applicable accounting standards.

This study is limited only to know and explain the application of SAK-ETAP on SMEs and the problems they faced. Data were obtained through a questionnaire survey using premises with direct observation and interviews conducted in the respondents (as representatives of business organizations), which is in accordance with what is going on and experienced by respondents. 


\subsection{Method of Data Collection}

This research used data collection techniques such as:

1. Questionnaire by giving questionnaires to the respondents

2. Interviews can be structured or unstructured, and can be done through face to face or by using the telephone.

3. Observation is a complex process, a process that is composed of a variety of biological and psychological processes. Two of the most important are the processes of observation and memory (Sugiyono, 1999, 130-134).

4. Direct inspection to the respondent, to find out the business processes related to the respondent's business.

There are several important points as a research instruments that want to be identified is as depicted in Table 4 below.

Tabel 4 Instruments

\begin{tabular}{|c|l|}
\hline No & \multicolumn{1}{c|}{ Instruments } \\
\hline 1 & Importance of financial statements for SMEs \\
\hline 2 & SME's was recording and bookkeeping accounting \\
\hline 3 & SMEs knows about the Accounting Standards for SMEs (SAK ETAP) \\
\hline 4 & SMEs was implementing the accounting standards in preparing the financial statements \\
\hline 5 & $\begin{array}{l}\text { Financial Statements of SMEs already have applied SAK ETAP, that has the following criteria : } \\
\text { - The recording of assets have been supported by the evidence in accordance with provisions } \\
\text { - The recording of the debt has been supported by the evidence in accordance with provisions } \\
\text { - The capital has been supported by the evidence in accordance with provisions } \\
\text { - The Budget realization report has been supported by the evidence in accordance with provisions } \\
\text { - The financial management has been no separation of functions and responsibilities } \\
\text { - The financial managers have to understand the financial administration in accordance with provisions }\end{array}$ \\
\hline 6 & Obstacles encountered in preparing the financial statements \\
\hline
\end{tabular}

\subsection{Data Analysis Techniques}

The steps in the research are as follows:

1. Tabulation of results of interview, observation, inspection, vouching or tracing documents,

2. Ranking of problems which are used to identify problems - primary problems, secondary problems, and so on,

3. Summing up the weaknesses and suggest improvements in the implementation of accounting in preparing the financial statements in accordance with SAK ETAP.

4. Present recommendations to the constituent or the entire business standards and the application of SAKETAP for SMEs that become more meaningful in the future.

\section{Results}

\subsection{Demographics of Respondents}

Based on the results of a questionnaire distributed to respondents, especially in the open-ended questions for the 25 respondents in the pilot project, information obtained were as follows: $64 \%$ male respondents and 35\% female respondents; out of those respondents, $4 \%$ were aged less than 25 years old, $8 \%$ were 26 to 30 years old, $28 \%$ were 31 to 35 years old, and $60 \%$ were above 36 years old. Based on information obtained, $64 \%$ respondents were owner of a company, $8 \%$ were Director, $12 \%$ held position in Accounting and Finance, $12 \%$ held other positions, and $4 \%$ did not fill in the position field. 
Moreover, the education level of $52 \%$ of them were high school or equivalent, $12 \%$ were diploma, $32 \%$ were graduate, and only $4 \%$ of them earned postgraduate degree. Specifically, the education background of $4 \%$ of the respondents were accounting, $12 \%$ were management, $20 \%$ were economics, and $64 \%$ were others. $44 \%$ of the business' background were trade, $4 \%$ were production, $40 \%$ were services, $4 \%$ were others.

Another overview describes the company's assets, number of employees, turnover and corporate funding sources. In terms of assets, 52\% companies have assets less than 500 million dollars, while $44 \%$ have more than 500 million, and $4 \%$ did not answer. Business units that employ less than 20 people were $76 \%$, more than 20 people were $16 \%$ and the rest did not provide an answer. Almost $84 \%$ of SMEs reached less than 500 million dollars on their business turnover during that year, while 12\% SMEs reached more than 500 million dollars, and the rest did not provide data on their turnover. Another important thing is the source of the business funding. $36 \%$ of respondents are using private funding to the portion of less than $50 \%$ and the remaining $64 \%$ use private funding more than half of the necessary funding.

Associated with the experience of getting funding from banks, the results showed that only $48 \%$ of the business units that have applied to bank credit, while 52\% have never done that. Among those who have ever applied to the bank for a loan, $16 \%$ of them never get funding more than USD 100,000,000.

$44 \%$ of the respondents' have only the accounting staff and only $40 \%$ have a special division for accounting. Only $40 \%$ of respondents prepare financial statements regularly. As for the financial statements showing SFAS background-ETAP, only $12 \%$ showed that and only $8 \%$ using a program for the preparation. And the most worrying is the lack of understanding, socialization and training regarding the respondents get SAK-ETAP.

For those respondents who did, they get the GAAP-based recording from self-learning and non-formal informed. Though they realize that the use of SFAS, they have not done a lot of things related to the formal accounting records. For respondents, accounting recognition through this research will be useful for some things which are from the recording of assets, debt, capital, balance sheet, income statement and budget realization report.

Table 5 Findings

\begin{tabular}{|c|l|r|r|}
\hline \multirow{2}{*}{ No } & \multicolumn{1}{|c|}{ Indicator } & \multicolumn{2}{|c|}{ Valid Precent } \\
& \multicolumn{1}{|c|}{ Yes } & \multicolumn{1}{c|}{ No } \\
\hline 1 & Importance of financial statements for SMEs & $44 \%$ & $56 \%$ \\
\hline 2 & SME's was recording and bookkeeping accounting & $62.5 \%$ & $37.5 \%$ \\
\hline 3 & SMEs know about the Accounting Standards for SMEs (SAK ETAP) & $20 \%$ & $80 \%$ \\
\hline 4 & $\begin{array}{l}\text { SMEs was implementing the accounting standards in preparing the financial } \\
\text { statements }\end{array}$ & $4.2 \%$ & $95.8 \%$ \\
\hline 5 & Financial Statements of SMEs already have applied SAK ETAP & $4 \%$ & $96 \%$ \\
\hline
\end{tabular}

Based on Table 5 shows that $44 \%$ of financial statements for SMEs becomes important and $56 \%$ consider the financial statements are not important, because the business they do have a little more than 500 million. Most of SMEs have been doing recording and accounting bookkeeping (62.5\%), but based on the findings in the field of SMEs constitute only a simple accounting records instead of financial statements in accordance with accounting standards (SAK ETAP). 20\% of SMEs know about the Accounting Standards for SMEs (SAK ETAP) and 80\% they did not know. SMEs have not implemented the accounting standards in preparing the financial statements, can be viewed from only $4.2 \%$ have implemented accounting standards SAK ETAP and $95.8 \%$ have not yet implemented, particularly in the recording and recognition of assets, debts, capital which is supported by the evidence accordingly.

Over all, only $4 \%$ of respondents understood the function of information in financial statements and know how to implementation accounting standards in SMEs (SAK ETAP). 


\subsection{Implementation of Accounting Standards For SMEs (SAK-ETAP)}

The research conducted, $20 \%$ of the respondents have assets below 500 million rupiah and $44 \%$ have assets above 500 million rupiah. From this information, the respondents had done right if they have started applying proper accounting records. Although respondents admitted that they have accounting staff about $44 \%$, but the financial statements they made are far from standard. Many of the respondents only made manual, unstructured record. The information they got from the financial statements was not optimal. The recording of transactions was carried out solely so they will not forget transactions they have done.

Based on the purpose of research and empirical data from respondents, they showed that the application of financial accounting standards has not been fully carried out, especially concerning the application of Financial Accounting Standards Entities without Public Accountant (SAK- ETAP). Based on Table 5, only 4\% of SMEs that have implemented it well. Therefore, these results cannot fully reveal the effect of the implementation of SAK-ETAP to the process of preparation of financial statements in SMEs as a whole. These results cannot be relied on either if we try to measure the effects on the performance of SMEs.

Constraints and obstacles faced by the respondents in the implementation of accounting standards (SAKETAP) in SMEs are no staff or competent person in preparing financial statements and no socialization or training about accounting standards for SMEs.

\section{Conclusions And Recommendations}

\subsection{Conclusions}

The capability of Small and Medium Enterprises (SMEs) in the economy of Indonesia currently gets support from various stakeholders, including government, banking and financial institutions as well as the community at large. However, in the implementation of accounting standards in the financial statements are still weak. Many SMEs only doing a simple the accounting records. The field data showed only $4 \%$ of all respondents who use accounting standards in preparing financial statements. Very ironic if we compare it with the important role of SMEs in GDP of nearly 58\%. Therefore, the indispensable role of agencies involved in supporting the development of SMEs in Indonesia, one of them in terms of making financial statements in accordance with generally acceptable accounting standards.

Most of a society that tends to pay less attention to the role and capabilities of SMEs, its business terms have been proved to have a contributed to the economic development. This was seen during the economic crisis in Indonesia that SMEs able to survive. In practice, there are still many problems that must be repaired, particularly in these study related to the financial statements. Why financial statements are a major concern, because of the financial statements provides information on the financial position, financial performance, and cash flows. The competent institutions such as government, the Indonesia Accounting Association (IAA) and related institution are expected to contribute to improving the implementation of accounting standards for SMEs.

\subsection{Limitations and Implications of The Research}

Limitations of this study is only identifies the implementation of accounting standards (SAK-ETAP) to SMEs. Moreover, it does not explain many things about the adoption process and the internal dynamics of the company in implementing accounting standards. This research was conducted in a limited area that might not represent the implementation of SAK-ETAP. Other drawback was that the study can't provide a clear answer to explain the relationship between the implementation of SAK-ETAP with various managerial aspects such as planning and financial accountability. 
Some suggestions can be submitted in this study are as follows, (1) Approaching the problems faced by SMEs in their business, (2) Socializing the form of financial reporting standards so that the operational business functions could be better (3) To provide training on the preparing of financial statements in accordance with the needs of SMEs.

This study shows that the implementation of accounting standards (SAK-ETAP) on SMEs are still far from the expectations and needs the intervention of various parties, both from the regulators, practitioners and academics.

\section{References}

Ardi Kusumah, Arief. (2012). Pengaruh Penerapan Standar Akuntansı Pemerıntahan Terhadap Kualıtas Laporan Keuangan (Survei pada SKPD/OPD Pemerintahan Kota Tasikmalaya). Fakultas Ekonomi Universitas Siliwangi (Implementation of the Government Accounting Standards The influence of on the quality of the Financial Statements (Survey on SKPD / OPD Tasikmalaya City Government). Faculty of Economics, University of Siliwangi), Retrieved from Journal.unsil.ac.id/download.php?id=283.

Auliyah, Iim Ma'rifatul. (2012). Penerapan Akuntansi Berdasarkan SAK ETAP Pada UMKM Kampung Batik Di Sidoarjo (Implementation of Accounting Based on SAK ETAP At SMEs in Kampung Batik Sidoarjo) (Master's thesis, Perbanas Economics School Surabaya).

Cheng, Jierong. (2015). Small and Medium Sized Entities Management's Perspective on Principles-Based Accounting Standars on Lease Accounting. Scientific Research Publishing 6, 71-76.

Indonesia Accounting Association. (2009). Standar Akuntansi Keuangan Entitas Tanpa Akuntabilitas Publik, (Financial Accounting Standards Entities Without Public Accountability) Per 1 Oktober, Jakarta: Dewan Standar Akuntansi Keuangan.

Kieso, Weygandt, Warfield. (2002). Intermediate Accounting, the tenth edition, Jakarta: Erlangga Publisher.

Megginson, William. L. Mary Jane Byrd, and Leon C Megginson. (2000). Small Business Management: An Entrepreneurs Guide Book, (3rd Ed). United States of America: McGraw Hill.

Rudiantoro, Rizki. (2012). Kualitas Laporan Keuangan UMKM serta Prospek Implementasi SAK ETAP (The quality of financial statements of SMEs and Prospects of Implementation SAK ETAP). Jurnal Akuntansi dan Keuangan Indonesia (Journal of Accounting and Finance Indonesia), 9 (1) 1 - 21.

Sarifah, Hani' Atun. (2012) Analisis Persepsi SAK-ETAP Terhadap Kinerja Usaha pada UMKM Se Kota Semarang (Perception Analysis of SAK-ETAP Toward SMEs Business Performance in Semarang). Accounting Analysis Journal, 1 (2). Retrieved from http://journal.unnes.ac.id/sju/index.php/aaj.

Seifert, Deborah L dan Deborah L. Lindberg. (2010). Key Provision of IFRS for Small and Medium-sized Entities. CPA Journal, Vol. 80 Issue 5, p34

Financial Accounting Standards Entities without Public Accountability (SAK-ETAP)Mei 2009

Susanto, Edi. (2011). Analisis Penerapan Standar Akuntansi Keuangan Untuk Entitas Tanpa Akuntabilitas Publik (SakEtap) Di UMKM Kelurahan Mojosongo Kecamatan Jebres Kota Surakarta (Analysis of Implementation the Financial Accounting Standard To Entities Without Public Accountability (SAK-ETAP) In the SME Sub Mojosongo Jebres District of Surakarta : Gigital Library Universitas Sebelas Maret, Surakarta.

Undang-undang Republik Indonesia Nomor 20 Tahun 2008 tentang Usaha Mikro, Kecil dan Menengah. (Law of the Republic of Indonesia Number 20 Year 2008 on Micro, Small and Medium Enterprises).

Tambunan, T. (2009). UMKM Di Indonesia (SMEs in Indonesia). Jakarta: Ghalia Indonesia Publisher.

Vasek, Libor. (2011). IFRS for SMES-A New Challenge for Worldwide Financial Reporting. International Journal of Management Cases, 13, 115-120. http://dx.doi.org/10.5848/APBJ.2011.00118. 